\title{
Effects of Fungi Contaminated Feed on the Growth and Survival of Clarias Gariepinus Juveniles
}

\author{
Akombo, Pauline Mbakaan ${ }^{1} \&$ Atile, John Iornyiman ${ }^{1} *$ \\ ${ }^{I}$ Department of Biological Sciences, Benue State University, Makurdi, Nigeria. \\ DOI: $10.46382 / M J B A S .2020 .4302$
}

The study was carried out to determine the effect of fungi contaminated feed on the growth and survival of catfish, Clarias gariepinus juveniles. This research was carried out for a period of twelve weeks. Forty catfish juveniles were stocked at a rate of twenty juveniles per plastic tank. Catfish juveniles in one tank were fed with moldy feed and the control was served with non-moldy feed and was observed for twelve weeks to determine and compare their growth and survival. Catfish juveniles fed with moldy feed had the highest mortality as well as slower growth as compared to the control fed with non-moldy feed. The survival rate of juveniles stocked was 55\% and mortality rate was $45 \%$ and majority of mortality was from juveniles fed with moldy feed and majority of the survival rate was from juveniles fed with non-moldy feed. Some water quality parameters such as temperature, dissolved oxygen and $p H$ were also taken and no significant difference was observed. Moldy feed or feedstuff should not be used as this can cause great mortality and therefore loss to fish farmers.

Keywords: Fungi contaminated feed, Growth, Survival, Clarias gariepinus.

\section{Introduction}

Fish and seafood constitute an important food component for a large section of the world population. They come after meat and poultry as staple animal protein foods where fish forms a cheap source of protein (Wafaa et al., 2011). Fish serve as an important source of human dietary protein worldwide, especially in African countries (kumolu et al., 2011). Catfish provides food for a lot of the populace in Africa. It allows for improved protein nutrition because of its high biological value in terms of high protein retention in the body. Protein assimilation in catfish is higher as compared to other protein sources and has low cholesterol (Adebayo et al., 2013).

Catfish production is important to the Nigerian economy. It serves as a source of income, reduces the rate of unemployment in the economy and increases the Gross Domestic Profit (GDP). In most countries, it fetches a higher price than tilapia as it can be sold live in the market as they have a market value two to three times that of tilapia (Emokaro, 2010). Catfish production is influenced by availability of fish feed and its quality. Fish feed quality, generally perceived as the responsibility of the feed manufacturer is affected by factors such as handling, storage and use. In the tropics, conducive environmental condition has majorly been attributed to production and growth of microorganisms and toxic substances; particularly fungi which can alter the quality of fish feed, limit the growth of fish and may result to fish mortalities (Adeniji et al., 2014).

These fungi are ubiquitous plant pathogens that are major spoilage agents of food and feedstuff. The infection of fungi can result into reduction in fish feed quality with contamination of poisonous fungal secondary metabolites called mycotoxins (Atanda et al., 2013).

Mycotoxins are toxic secondary metabolites produced by wide range of fungi (molds) toxic to humans, livestock and plants which explains the major concern of food and feed industries in preventing them from entering the food chain (Pierre, 2007). Mycotoxins are mainly produced by Aspergillus, Penicillum and Fusarium genera which invade crops in the field and may grow during storage under favourable conditions of temperature and humidity. 
Mold infestation in stored feeds, reduces nutritional value owing to loss of dietary lipids, amino acids and vitamins by enzymatic digestion making the feeds to have poorer flavour, appearance and less palatable (Lim et al., 2008).

\section{Materials and Methods}

\section{Experimental Location}

This research was conducted in the Zoology Laboratory, Department of Biological Sciences, Benue State University, Makurdi, Nigeria, located on latitude $7^{\circ} 43^{\prime}\left(7.7285^{\circ}\right)$ North and longitude $8^{\circ} 33^{\prime}\left(8.5540^{\circ}\right)$ East (Google Earth, 2017).

\section{Collection of Clarias gariepinus Juveniles}

Forty Catfish (Clarias gariepinus) juveniles were obtained from a commercial fish farm in Makurdi, Benue State, Nigeria. They were transported to the Zoology Laboratory, in plastic buckets half filled with water.

\section{Determination of Initial Length and Weight}

The initial individual weights and lengths were measured. The weights were determined individually using the weighing balance and their lengths were taken using a measuring board. They were then randomly distributed to the two plastic tanks. The volumes of water in the tanks were maintained at 206 litres at a stocking rate of twenty juveniles per plastic tank.

\section{Collection of Feed Samples}

A bag of moldy (presence of grey mold) and another bag of non-moldy feeds were sorted and purchased from a fish feed store at High Level market, Makurdi, Benue State, Nigeria. Both feed samples were Top feeds. The nutrient component of the feed was labeled by the manufacturer as shown in Table 1 below.

Table 1: Feed composition

\begin{tabular}{|c|c|}
\hline Nutrient & \% Level \\
\hline Crude protein & 45 \\
\hline Crude fat & 10 \\
\hline Crude fibre & 3.0 \\
\hline Ash & 7.0 \\
\hline Calcium & 1.5 \\
\hline Total phosphorus & 1.1 \\
\hline Lysine & 2.4 \\
\hline Methionine + cystein & 1.4 \\
\hline \multicolumn{2}{|c|}{ Additives } \\
\hline Vitamin A & $700 \mathrm{Iu} / \mathrm{kg}$ \\
\hline Vitamin D & $850 \mathrm{Iu} / \mathrm{kg}$ \\
\hline Vitamin E & $50 \mathrm{mg} / \mathrm{kg}$ \\
\hline Vitamin C & $200 \mathrm{mg} / \mathrm{kg}$ \\
\hline
\end{tabular}

Source: Premier Feed Mills Company Limited. A subsidiary of Flour Mills of Nigeria PLC (2018) 


\section{Isolation and Identification of Fungal Microorganisms from the Feed}

Twenty grams of potato dextrose agar (PDA) was dissolved in five hundred milliliters (500ml) of distilled water and allowed to homogenize. The medium was then heated on the heating mantle to further dissolve particles and later sterilized by autoclaving in an autoclave at $121^{\circ} \mathrm{C}$ for about thirty minutes. An antibiotics (Chloramphenicol) was added to the medium (to inhibit the growth of any bacterial species that could contaminate the isolate), before pouring the melted medium into sterile Petri dishes and cooled at room temperature to solidify. One gram of moldy feed sample was ground using mortar and pestle to prepare a 10- fold serial dilution. This was then inoculated on the prepared medium plates and incubated at $25^{\circ} \mathrm{C}$ for 5-10 days. Developed colonies of fungi were sub cultured to obtain pure cultures. The fungi cultures were examined both macroscopically and microscopically for colony, mycelia, hyphae, conidia heads and spore characteristics. The characteristics were compared with those in a standard mycology textbook and chart (Olga, 1986).

\section{Fish Feeding}

Feed 1 was moldy free and served as control while feed 2 was moldy in appearance. Fish were fed at $5 \%$ body weight twice a day at 9:00am and 6:00pm for a period of 12 weeks. The ration was adjusted every week when the new weights of the juveniles for the various experimental tanks were determined. Feeding was done by hand. After washing hands and dry cleaning with a hand towel, the feed was fetched and spread evenly on the water surface of each tank.

\section{Water Quality Parameters}

\section{Temperature}

The weekly water temperature was measured using a portable thermometer, model JPB-607. The thermometer was switched on and reset to zero. It was then dipped in the plastic tank (at the center) and readings were taken when stabilized.

\section{Dissolved Oxygen}

Weekly dissolved oxygen was measured using a portable dissolved oxygen meter, model JPB-607. The dissolved oxygen meter was switched on and reset to read at zero after which it was dipped in the tank and the readings were read and recorded when they stabilized.

\section{pH}

The $\mathrm{pH}$ concentration was measured using Hanna water proof $\mathrm{pH}$ meter. The $\mathrm{pH}$ meter was reset at zero point and dipped in the center of the plastic tank. The readings were taken and recorded after stabilizing.

\section{Data Analysis}

The evaluation for growth and survival rate was carried out as follows:

$$
\text { Mean initial weight }(M I W)=\frac{\text { Total initial weight of juveniles }}{\text { Total number of juveniles }}
$$


Mean weight gain $(M W G)=$ mean final weight-mean initial weight

Growth rate $=\frac{\text { Mean final weight }- \text { Mean initial weight }}{\text { Duration of experiment }} \times \frac{100}{1}$

Percentage survival $=\frac{\text { Initial number of fish stocked }- \text { Number of dead fish }}{\text { Initial number of fish stocked }} \times \frac{100}{1}$

Mortality rate $=\frac{\text { Number of deaths during period of experiment }}{\text { Total number of juveniles }} \times \frac{100}{1}$

\section{Results}

The results of the fungi isolated are presented in the table 2 below with Aspergillus and Penicillum as the predominant fungi genera.

Table 2: characterization of fungal isolates from fish feed sample on PDA

\begin{tabular}{|l|l|l|}
\hline Macroscopic Characters & Microscopic Characters & Probable Organism \\
\hline $\begin{array}{l}\text { Colony colour ranged from } \\
\text { grayish to dark blue in } \\
\text { colour. }\end{array}$ & $\begin{array}{l}\text { The conidia colour was dark green to blue. } \\
\text { Conidiophores length was 265-365 } \mu \mathrm{m} \text { and it was } \\
\text { uncoloured to grayish brown. }\end{array}$ & Aspergillus fumigatus \\
\hline $\begin{array}{l}\text { Colony colour was parrot } \\
\text { green to deep green. }\end{array}$ & $\begin{array}{l}\text { Conidia were light green in colour. Conidiophores } \\
\text { length ranged from 550-678 } \mu \mathrm{m}\end{array}$ & Aspergillus flavus \\
\hline $\begin{array}{l}\text { The colour of the colony was } \\
\text { grayish to dark green with a } \\
\text { Chite dark border. Growth } \\
\text { rate moderate to rapid. }\end{array}$ & $\begin{array}{l}\text { stipes terminating in well-defined venticils of 3-5. } \\
\text { Conidia were spherical to subspherical with smooth } \\
\text { walls borne on fine columns }\end{array}$ & Penicillium digitatum \\
\hline
\end{tabular}

Source: Elise, et al., (2016)

Table 3: Survival, mortality and growth rate of juveniles during the study

\begin{tabular}{|l|c|}
\hline Growth parameters (grams) & \\
\hline Mean initial weight & $1.61 \mathrm{~g}$ \\
\hline Mean weight gain & $15.62 \mathrm{~g}$ \\
\hline Growth rate & $130.17 \mathrm{~g}$ \\
\hline Percentage survival (\%) & $55 \%$ \\
\hline Mortality rate (\%) & $45 \%$ \\
\hline
\end{tabular}




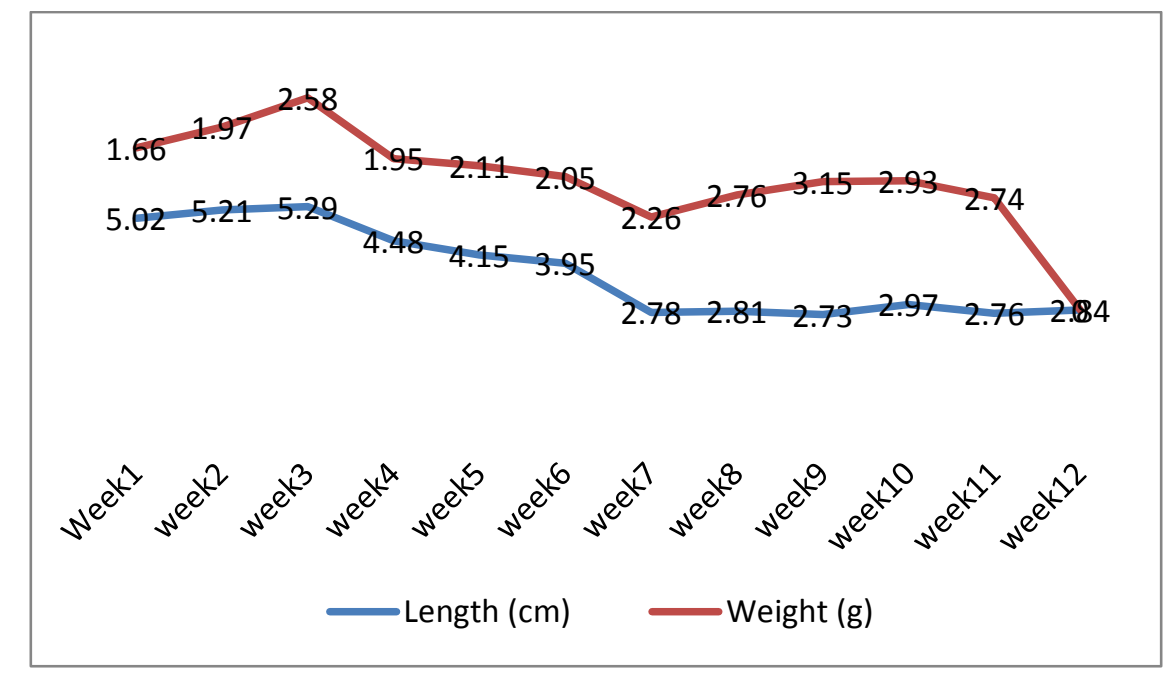

Fig.1 Moldy feed (Mean length and weight) growth

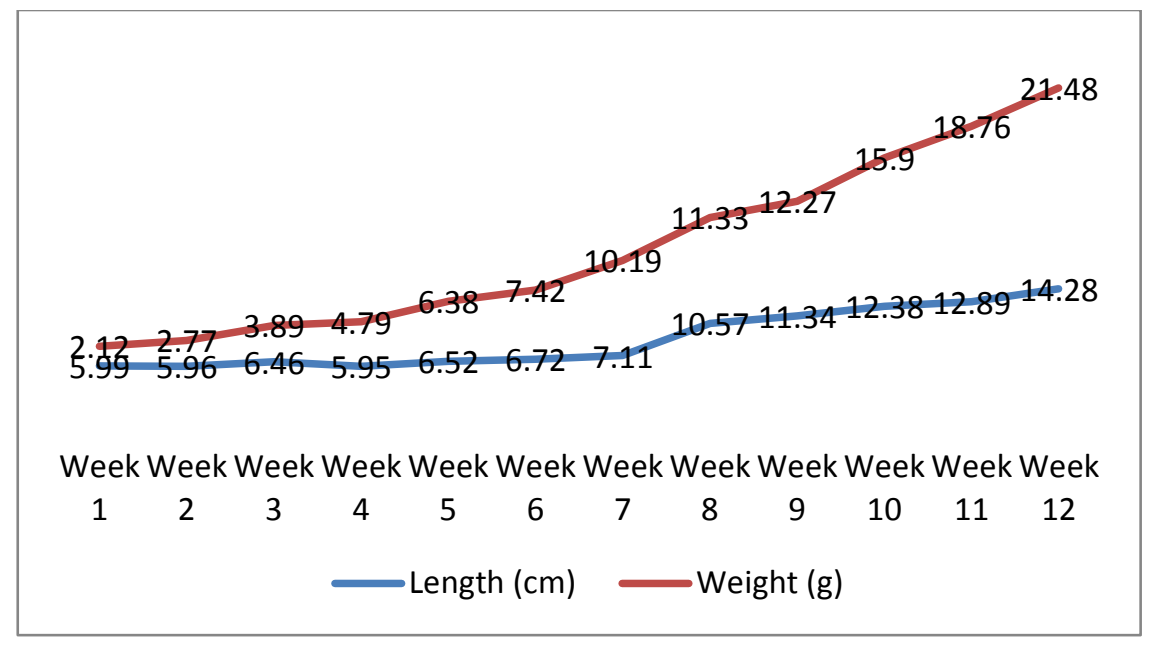

Fig.2 Non moldy feed (Mean length and weight) growth

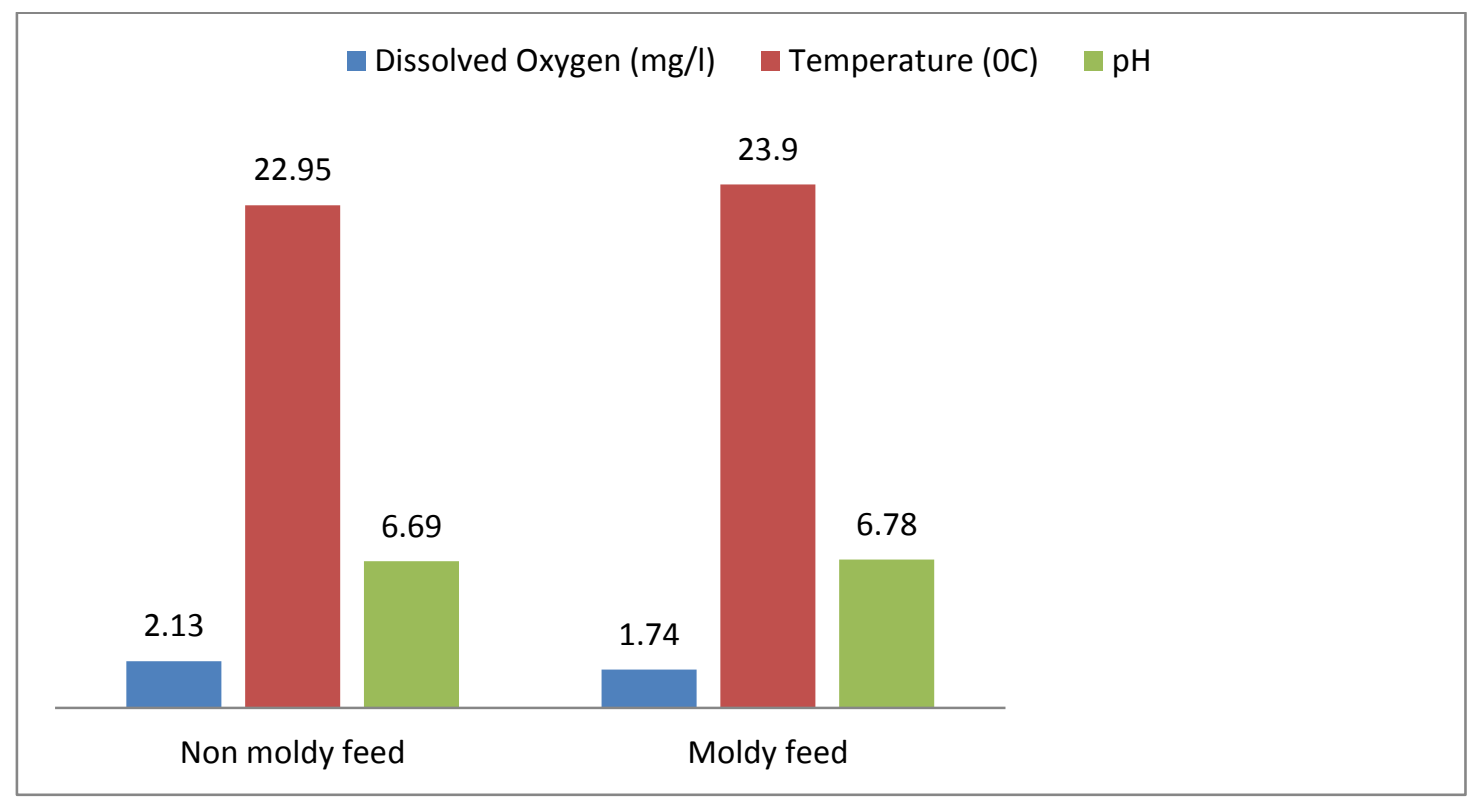

Fig.3 Mean dissolved oxygen, $\mathrm{pH}$ and temperature during the study 


\section{Discussion}

In this study, the results of fungi isolated from moldy feed showed Aspergillus and Penicillum as the predominant fungi genera as also stated in the work of Ariyo et al., (2013). Mycological examination was carried out for 150 samples of fish rations by El- Boshy et al., (2008) and a total prevalence of Aspergillus flavus was observed to be $66.6 \%$. Further, El- Boshy, isolated fifteen aflatoxin $\mathrm{B}_{1}$ producers. Again El- Boshy observed that various changes such as sluggish swimming, darkening of skin, loss of reflexes, increase in mucus secretion, loss of scales and ascities were in aflatoxin $\mathrm{B}_{1}$ intoxicated fish. Internally, the study showed that the liver displayed pale coloration with patches of congestion and hemorrhage, the spleen and the kidneys were darker in colour and appeared to be enlarged and congested. More so, growth rate of catfish juveniles fed moldy feed was seen to be slower than catfish juveniles fed with non-moldy feed. This could be due to less consumption of feeds by juveniles fed with moldy feed. This study is similar to Oluwafemi (2009) who carried out a study to investigate the performance of catfish fed with three different doses of aflatoxins isolated from fish feeds. The study showed that the growth of aflatoxicosed fish was significantly different from the control. More over protein, cholesterol, bilirubin, electrolytes and liver enzymes such as Aspartate transaminase (AST), Alanine transaminase (ALT) and Alkaline phosphate (ALP) were also significantly different from the control and the liver was observed to be severely damaged. Caguan et al., (2004) reported loss of appetite, decreased mean total biomass and low survival percentage in tilapia when fed with aflatoxin contaminated feed.

Furthermore, a higher mortality was recorded with the juveniles fed with moldy feed compared to juveniles fed with non-moldy feed. Out of the twenty juveniles stocked and fed with moldy feed, fifteen died and only five survived within a period of twelve weeks while out of twenty juveniles that were stocked and fed with non-moldy feed, three died and seventeen survived within duration of twelve weeks giving a mortality rate of $45 \%$ (Table 2). This result is similar to the findings of Adeniji et al. (2014) who carried out similar studies on Heterobranchus longifilis and obtained similar results.

In addition, lower weight gain and high mortality of juveniles fed with moldy feed as compared to juveniles fed with non-moldy feed was observed in this study (Fig. 1 and 2). This could be due to low feed consumption as presence of fungi reduces the nutritional value of feed and makes it less palatable (Lim et al., 2008). The results showed a significant difference in the growth and survival of catfish fed moldy feed and catfish fed non-moldy feed. The result of this study is similar to Francis et al., (2010) who evaluated the effect of dietary fumonisin $\mathrm{B}_{1}$ on the fingerlings of Clarias gariepinus. The diets used contained approximately 5, 10 and $15 \mathrm{mg} \mathrm{FB} / 1 / \mathrm{kg}$ respectively and the weight gain was noted to have reduced significantly.

The water parameters were all within a tolerable range for the growth of the juveniles. This could be attributed to low stocking density of the fish per tank, constant monitoring of the selected physicochemical parameters and addition of fresh water to the tanks. Again, some physico-chemical parameters taken within the period of this experiment showed no significant difference in the tank with juveniles fed with moldy feed and those fed with non-moldy feed. The water parameters were all within a tolerable range for the growth of juveniles (Fig. 3). There 
was no significant difference in the physico-chemical parameters taken, so the difference in growth, survival and mortality rates of the juveniles was influenced by moldy and non-moldy feed.

\section{Conclusion}

During the study, Aspergillus and Penicillium were the predominant fungi genera isolated and identified from the moldy feed. It was observed that juveniles fed with moldy feed had slower growth, lower survival rate and higher mortality as compared to juveniles that fed on non moldy feed. Survival rate of juveniles fed with moldy feed was five and mortality was fifteen. It was observed that the juveniles that were fed with moldy feed showed normal growth from the beginning but eventually died when they could no longer tolerate the feed which resulted to their death. Some water quality parameters such as temperature, dissolved oxygen and $\mathrm{pH}$ measured were all within a tolerable range for the growth and survival of the juveniles.

\section{Recommendation}

Fish farmers should use only non moldy feed to feed their fish. Also, sellers of fish feeds should properly handle fish feeds to avoid infestation and contamination by mold.

\section{References}

Adebayo, O.O and Akinwande, D.O. (2013). Economic Analysis of catfish (Clarias gariepinus) production in Ibadan metropolis: Discourse Journal of Agriculture and Food Sciences, 1(7), 128-134

Adeniji, C. A, Okiki, P. A, Rasheed, A. M and Bolaji, R. (2014). Mouldy groundnut cake and hydrated sodium aluminosilicate in practical diet for African Catfish Clarias gariepinus (Burchell, 1822). Fisheries and Aquaculture Journal, 4, 83-85

Ariyo, L. A, Anthony, H. M and Lami, H. M. (2013). Survey of mycotoxigenic fungi in concentrated poultry feed in Niger State, Nigeria. Journal of Food Research, 2(2), 128-135.

Atanda, O and Edema, M.O. ( 2013). Fungal and mycotoxin contamination of Nigerian foods and feeds. Journal of Microbiology Research, 2:1-8

Bagenal, T.B. (1978). Aspects of fish fecundity, 75-95. In:S.D.Gerking (ed) Ecology of Freshwater Fish Production, Blackwell Scientific. Oxford England. Pp. 124-131

Cagauan, A. G, Tayaban, R. H, Somga,J and Bartolome, R. M. (2004). Effect of aflatoxin contaminated feeds in Nile tilapia (Oreochromis niloticus L.) Journal of Basic and Applied Zoology, 56-79.

El - Boshy, M. E, El- Ashram, A. M and El- Ghany, N. A. (2008). Effect of dietary beta - 1,3 glucan on immunomodulation on diseased Oreochromis niloticus. Journal of Food Control, 1109-1127.

Elise, M., Stéphanie, L., Leslie, A., Pascal, A., Jean-Marc, C., Vincent, F., Benoit, B., Eric, D., Jacques, G., Jean-Winoc, D., Anne, B. and Françoise, B.(2016). Characteristics of Aspergillus fumigatus in Association with Stenotrophomonas maltophilia in an In Vitro Model of Mixed Biofilm. PLoS One, 11(11), e0166325. 
Emokaro, C. O, Ekunwe, P. A and Achille, A.(2010). Profitability and viability of catfish farming in kogi State, Nigeria. Journal of Agriculture and Biological Sciences, 6(3), 215-219.

Francis, A. G, Adewole, A. M, Oginni, O, Mercy, F, Ayodeji, O, Bada, M and Akele, O. (2010). Growth performance, haematology and serum biochemistry of African catfish (Clarias gariepinus) fingerlings fed graded levels of dietary fumonisin B1. Mycotoxin Research 26, 221-227

Kumolu-Johnson, C. A and Ndimele, P. E. (2011). A review on post-harvest losses in Artisanal fisheries of some African countries. Journal of Fisheries and Aquaculture Sciences, 6, 365-378.

Lim, H. A, Lim, S. L and Ibrahim, C. O. (2008). Contamination of palm kernel meal with Aspergillus flavus and its nutritive value in pelleted fish feed for Tilapia, Oreochromis mossambicus. Journal of Aquaculture Research, 32 , $895-905$.

Oluwafemi, (2009). Performance of catfish fed different doses of aflatoxin in diets. Asset 8(2), 15-24.

Pierre, A.C, Richard, J. L and Cysewski, S.J. (2007). The implication of aflatoxin in animal diseases. Journal of American Veterinary Medical Association, 176 (8), 719-722

Wafaa, M.k, Bakr, Walaa, A. H and Amani F. A. (2011). Detection of Salmonella and vibrio species in some seafood in Alexandria. Journal of American Science, 7(9), 663-668 